\title{
O ano de 1993: \\ distopia e direitos humanos
}

Regina Zilberman a (1)

\begin{abstract}
Resumo
O ano de 1993, de José Saramago, publicado em 1975, retrata uma sociedade invadida por uma nação estrangeira despótica que oprime a população nativa. A data indicada no título, em contraposição à da publicação do livro, aponta para um futuro catastrófico, o que associa o poema ao gênero distópico. As atrocidades cometidas violam os direitos civis dos habitantes do país ocupado. Assim, $\mathrm{O}$ ano de 1993 faculta uma reflexão sobre as relações entre o gênero distópico e o exercício das políticas em nome dos direitos humanos em um texto literário.
\end{abstract}

Palavras-chave: José Saramago. Poesia. Distopia. Direitos humanos.

a Universidade Federal do Rio Grande do Sul, Instituto de Letras, Programa de Pós-Graduação em Letras, Porto Alegre, RS, Brasil. E-mail: regina.zilberman@gmail.com 


\begin{abstract}
A Europa jaz, posta nos cotovelos: De Oriente a Ocidente jaz, fitando, E toldam-lhe românticos cabelos Olhos gregos, lembrando.

A mão sustenta, em que se apoia o rosto. Fita, com olhar esfíngico e fatal, O Ocidente, futuro do passado. O rosto com que fita é Portugal.
\end{abstract}

Fernando Pessoa

1 Todas as citações extraídas de $O$ ano de 1993 provêm desta edição, indicando-se doravante somente as páginas onde se encontram.

\section{De José Saramago para Salvador Dali}

Publicado por José Saramago em 1975, O ano de 1993 é um poema dividido em trinta segmentos numerados a que chamaremos capítulos, começando com a evocação de uma pintura não nomeada de Salvador Dali. Segundo a descrição que ocupa a primeira parte do capítulo inicial, aparecem, no quadro, "sombras muito recortadas", um "sol que diremos parado" e pessoas que "estão sentadas na paisagem entre dois prumos de madeira que foram uma porta sem paredes para cima e para os lados" (SARAMAGO, 2014, p. 1081). ${ }^{1}$ Reconhecem-se, na pintura, ao menos duas pessoas, sendo que uma delas "vai riscando no chão uns traços enigmáticos que tanto podem ser um retrato como uma declaração de amor ou a palavra que faltasse inventar" (p. 1082).

O narrador não informa o título do quadro escolhido, limitando-se a identificar sua autoria, atribuída a Salvador Dali, que considera "mau pintor", contudo, com a suficiente qualificação para traduzir figurativamente "a imagem necessária para os dias de 1993" (p. 1081). A pintura poderia ser Reminiscência arqueológica d'O angelus, de Millet, reproduzida a seguir: 
${ }^{2}$ Cf. Angelus

(pintura). In: https:// pt.wikipedia.org/wiki/ Angelus_(pintura).

Acesso em: 25 set 2020.

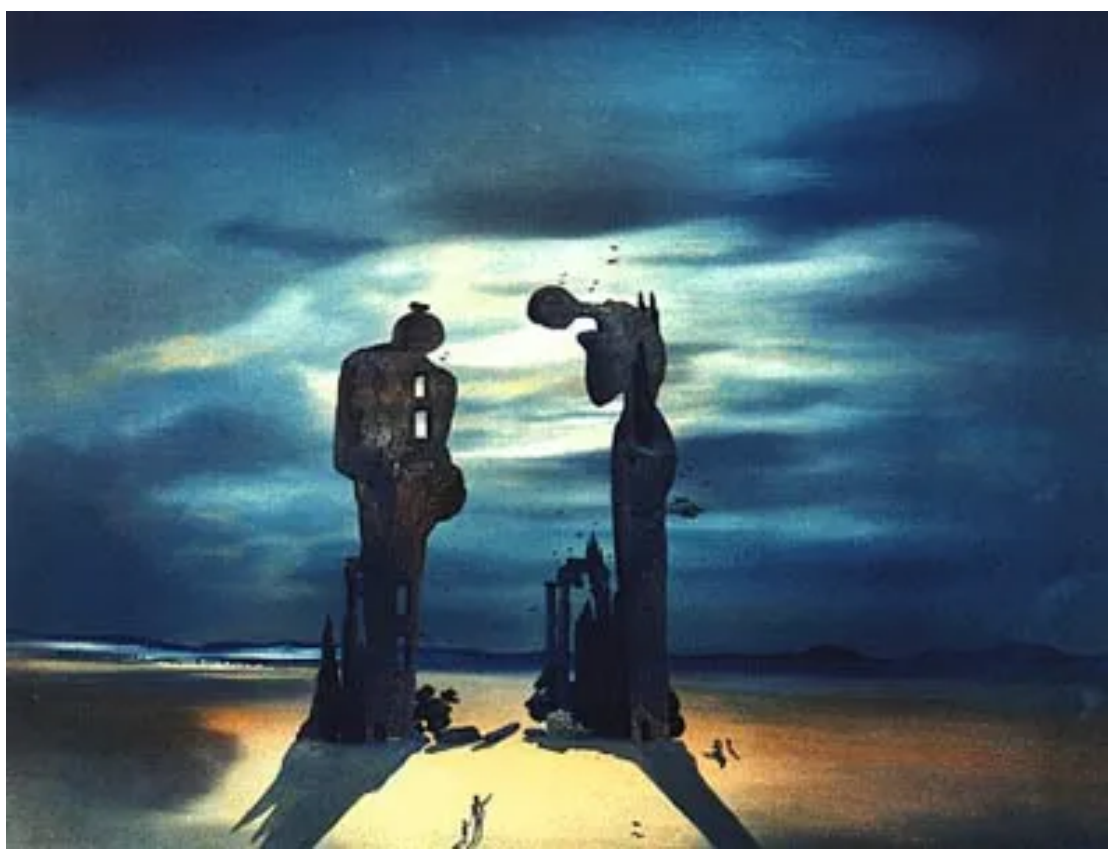

Figura 1 - Reminiscência arqueológica d'O angelus, de Millet

Fonte: https://i2.wp.com/virusdaarte.net/wp-content/uploads/2014/05/dalia.png

Salvador Dali compôs o quadro a partir da obra do francês Jean-François Millet, intitulada Angelus, dívida confessada em seu título, que é, em certo sentido, uma citação. O quadro original apresenta um casal junto à sua lavoura, em posição de quem faz uma prece, com as cabeças voltadas para a terra. ${ }^{2}$ Salvador Dali altera o ambiente, agora árido; mas, embora agigante as figuras humanas, mantém seu posicionamento e atitude servis. Além disso, procede a intervenções, destacandose primeiramente as duas pessoas colocadas na parte inferior, à esquerda, dentre elas um adulto que aponta para a imagem, supostamente comentando para uma criança o que vê.

Trata-se, pois, de uma segunda citação, interpolada ao cenário que motivou a criação de Dali. Transpondo-a para o ambiente de $O$ ano de 1993, talvez coincidam com os indivíduos a que se refere o narrador de Saramago no sétimo parágrafo de $O$ ano de 1993: "E as pessoas não se sabe quantas não foram contadas devem ser ao menos duas porque conversam levantam as golas dos casacos para se defenderem do frio" (p. 1081).

Em lugar intermediário, nem espectadores como o adulto e a criança, nem matéria de contemplação, Salvador 
Dali, em outra intervenção, posiciona mais duas figuras, uma delas aparentemente abaixada. Pode ser que correspondam às criaturas mencionadas no décimo e no décimo terceiro parágrafos: "Uma das pessoas vai riscando no chão uns traços enigmáticos que tanto podem ser um retrato como uma declaração de amor ou a palavra que faltasse inventar / [...] / Uma sombra estreita e comprida toca no dedo que risca a poeira do chão e começa a devorá-lo." (p. 1082).

As proximidades entre a obra de Salvador Dali e o capítulo de abertura de $\mathrm{O}$ ano de 1993 podem ser tanto fortuitas, quanto arbitrárias. De toda maneira, oferecem informações sobre o livro de 1975, que, mais adiante, em sua trajetória artística, José Saramago incluiu entre os de seus versos, ao lado dos anteriores Os poemas possiveis, de 1966, e Provavelmente alegria, de 1970.

Com $O$ ano de 1993, José Saramago parece encerrar sua carreira de poeta, o que pode ser creditado a seu sucesso como ficcionista, e especialmente como romancista (OLIVEIRA, 2012). Por seu turno, essa obra traz consigo algumas questões que, mesmo reaparecendo em narrativas consagradas (COSTA, 1997), justificam a atenção a ser dada a ela.

Uma das informações sugeridas pela explícita associação a Salvador Dali, e destacada pelos estudos dedicados ao poema, é sua aparente filiação ao Surrealismo (SILVA, 2018; BALTRUSCH, 2020). Outra pode relacionar-se ao ambiente traduzido na pintura: a recordação da morte, o luto e a melancolia, as figuras humanas reiterando a posição desesperançada do protagonista, que, por analogia, relembra a do ser alado presente na clássica gravura renascentista de Albrecht Dürer.

Salvador Dali retrata uma paisagem desértica, em que a vida social está ausente. Há três pares de pessoas que se distinguem tanto por suas ações, quanto por suas dimensões. As duas maiores, um homem e uma mulher, de cabeças baixas, parecem rezar, tal como na pintura de Jean-François Millet; as duas menores, colocadas na parte inferior esquerda do quadro, testemunham a súplica do casal, sendo que uma delas, o adulto, aparentemente comenta o que vê, erguendo o braço direito para reforçar o teor de sua fala. $\mathrm{O}$ terceiro grupo, próximo do primeiro, não olha para nenhum dos outros dois, voltando sua atenção a algo que está junto à terra. $\mathrm{O}$ modo como se 
distribuem as figuras na tela transforma o adulto e a criança em espectadores afastados de um acontecimento; assim, a pintura apresenta simultaneamente a cena e o comentário de cena. Não fosse uma imagem, e sim um texto, o comentário corresponderia a um prólogo - vale dizer, a um paratexto. Ou a uma citação metalinguística - ou metapictórica -, adequandose o termo ao universo das artes plásticas.

É esse o papel que desempenha o capítulo de abertura de $O$ ano de 1993. Só que José Saramago inverte o processo: a expressão verbal traduz a imagem, tornando-a cenário de uma pintura. OSurrealismo do quadro original migra para o poema, explicitando sua filiação àquela poética, escolhida por ser a única capaz de dar conta do ambiente devastado e desprovido de humanidade que exporá nos versos subsequentes.

O capítulo dois dá início à narrativa, constituída, como também ocorre na abertura, por meio de orações separadas em parágrafos e não pontuadas. É o espaço gráfico entre um e outro parágrafo, ao lado do emprego da maiúscula no começo das frases, que assegura o início e o final de cada período. Cada uma dessas sentenças poderia ser considerada um verso - ou versículo, como sugerem estudiosos da obra (SOUZA, 2007) -, já que, como se observou antes, José Saramago inclui $O$ ano de 1993 entre seus poemas. Por sua vez, o título, imaginando acontecimentos que ocorrem quase vinte anos depois da data de publicação do livro, bem como a atmosfera desolada, constituída desde o capítulo inicial e ilustrada por uma possível pintura de Salvador Dali, vinculam o texto à classe das distopias, gênero de narração transcorrida em futuro próximo ou distante em que valores idealizados pela sociedade, como liberdade e justiça, degeneram em formas de totalitarismo, ilegalidade, violência e desigualdade.

Utilizando recursos da literatura em versos, O ano de 1993 talvez consista em um dos poucos exemplos de uma criação literária de caráter distópico veiculada por meio da poesia.

\section{Distopias}

Distopias costumam ser premonitórias ou, pelo menos, pretendem ser. Partem de um evento - político, social, tecnológico - da atualidade e projetam seus desdobramentos no tempo. Como aqueles fatos comportam elementos negativos 
- injustiças, disparidades, controle coletivo -, seu avanço resulta em prejuízo para os indivíduos que os vivenciam.

Em um dos primeiros e mais conhecidos exemplos do gênero no século XX, o romance Admirável mundo novo, de 1932, Aldous Huxley imagina o que poderá acontecer se a sociedade industrial se expandir, a ponto de transformar a família em uma unidade produtiva, tanto mais eficaz quanto menos interferirem sentimentos e emoções, neutralizadas por efeito de psicotrópicos. Também prognostica o impacto do marketing e da cultura de massa sobre a sociedade, turvando a compreensão da história e da tradição, e anulando a criatividade. O mundo novo é um universo de iguais robotizados, seres voltados ao próprio prazer, incapazes de almejar algum tipo de mudança ou expressar rebeldia ou inconformidade.

Em 1984, lançado em 1949, George Orwell inspira-se no totalitarismo stalinista, vigente à época de redação da obra e soberano na União Soviética, para construir um universo ficcional dominado por um estado centralizador que invade a vida das pessoas, determinando seus destinos e sufocando os descontentes. A Oceânia, governada pelo Grande Irmão, é também o mundo da pós-verdade - ou dos "fatos alternativos" - em que a história é refeita para convir aos detentores do poder.

De1953 é o romance Farenheit 451, de Ray Bradbury, situado igualmente em uma sociedade do futuro, caracteristicamente um Estado policial, em que a dissidência é proibida. Livros impressos são perseguidos e queimados, porque considerados subversivos. Em lugar deles, impera a televisão, que desvia a atenção das pessoas para assuntos leves e irrelevantes. Em $O$ conto da aia, de 1985, Margaret Atwood desenha uma nação localizada na América do Norte que, ocupando o espaço dos outrora Estados Unidos, é controlada pelo fundamentalismo religioso, calcado na submissão das mulheres, encarregadas tão somente de conceber herdeiros para uma sociedade machista e homofóbica. Kazuo Ishiguro, em Não me abandones jamais, de 2005, conta a história de três jovens cujo nascimento resulta de

${ }^{3}$ Sobre as relações entre o poema de Saramago e as obras de Huxley, Orwell e Bradbury, cf. PICCHIO (2000) e SGARBI (2013). técnicas de clonagem, o que o leva a expor, por meio do drama das personagens, os conflitos decorrentes do assombroso desenvolvimento tecnológico do século XX.

$O$ ano de 1993 situa-se confortavelmente nesse arco temporal, pois sucede aos livros de Huxley e Orwell, ${ }^{3}$ mas 
precede aos dos demais autores citados. E dá início a uma vertente da obra de José Saramago, que, mais adiante, retoma o gênero distópico em romances como Ensaio sobre a cegueira, de 1995, Todos os nomes, de 1997, A caverna, de 2000, e Ensaio sobre a lucidez, de 2004.

Contudo, a integração de $O$ ano de 1993 àquele gênero não se dá de modo imediato. A obra abre com um prólogo que, como se observou, a identifica à poética surrealista, de teor onírico, e não realista, ao contrário da tendência associada às distopias. O capítulo seguinte conserva o teor surrealista do poema, ao descrever a situação dos moradores de uma cidade não nomeada em um tempo não determinado: "Os habitantes da cidade doente de peste estão reunidos na praça grande que assim ficou conhecida porque todas as outras se atulharam de ruínas" (SARAMAGO, 2014, p. 1083).

Segundo o narrador, a população está paralisada pela praga que assola a cidade e alastra-se: "Alguma coisa podia talvez suceder no mundo antes do triunfo final da peste nem que fosse uma peste maior". Por isso, como sugere o quinto verso, "ali estão pois na praça angustiados e em silêncio à espera" (p. 1083). Esse início poderia ser o de Édipo, tragédia de Sófocles, cujo título alude ao herói mítico que reina sobre uma Tebas arrasada por uma epidemia. Ou o começo de $A$ peste, de 1947, romance de Albert Camus que transcorre em Oran, na Argélia, tomada por ratos transmissores de doença, combatidos pelo protagonista, Dr. Bernard Rieux.

Ao contrário, porém, das obras de Sófocles e de Albert Camus, em $O$ ano de 1993, a cidade não identificada e seus habitantes anônimos situam-se, à primeira vista, fora do tempo, mas perante algo que pode acontecer a qualquer momento, em futuro próximo ou distante: "alguma coisa [que] podia talvez suceder" (p. 1083). É o adiantar do tempo que associa a narrativa às características da distopia, a que se soma a hipótese de que o que quer que venha a acontecer será nefasto: $\mathrm{o}$ "triunfo final da peste" ou então "uma peste maior". Por isso, a população, "os homens e as mulheres" que a compõem, carece de esperança, deixando-se "cair no pavimento estalado da praça"; longe, estão os campos, mas esses mostram-se "devastados" (p. 1084). O capítulo 2 estampa, pois, um conjunto de pessoas atônitas ante a ameaça da destruição, futuro a concretizar o sentimento de 
aflição da atualidade. O grupo humano, inteiramente à mercê do destino, aguarda que o pior se manifeste, sem se rebelar.

É no capítulo 3 que marcas do tempo se introduzem na narrativa, colocando os acontecimentos no contexto da tecnologia do século XX. Assim, o narrador alude ao elevador que "deixou de funcionar" (p. 1085), máquina que conduziria os moradores ao vigésimo andar de um prédio. Também o capítulo 11 refere-se a produtos típicos da época em que o poema foi escrito: os "termômetros da cidade" (p. 1101) e, sobretudo, os meios de comunicação de massa, como o rádio e a televisão. Antes disso, no capítulo 4, introduz-se um computador, cuja função é aquilatar o teor de verdade nas respostas a um inquérito a que uma pessoa é submetida.

A alusão ao elevador inutilizado não visa apenas situar cronologicamente a narrativa; importa também enquanto representação da imobilidade em que foram jogados os seres humanos, que, na praça do capítulo 2, mostram-se estáticos e que, nos altos edifícios do segmento seguinte, não dispõem de alternativas para se movimentar no espaço circundante. $\mathrm{O}$ capítulo 4 complementa o diagrama da sociedade representada em $O$ ano de 1993: nela, exerce-se o pleno controle social, calcado na repressão e na tortura. Assim, o narrador abre o trecho com a menção ao "interrogatório do homem" que já dura quinze dias e não dá mostras de terminar, embora seu crime tenha sido tão somente ter saído de casa "depois da hora de recolher" (p. 1087).

A imposição de um horário de recolher é de antemão um sintoma da repressão, desenhando a cidade sitiada descrita no capítulo 5. Antes, o narrador explicita o "método novo" (p. 1087) aplicado às investigações policiais: "Os inquiridores fazem uma pergunta em cada sessenta minutos vinte e quatro por dia e exigem cinquenta e nove respostas diferentes para cada uma" (p. 1087).

O interrogatório - fundado na noção de que "é impossível não estar a resposta verdadeira entre as cinquenta e nove que foram dadas" (p. 1087) - não difere dos métodos utilizados pelos inquisidores à época de atuação do Santo Ofício ou das devassas a que se sujeitaram conjurados como Silva Alvarenga, quando esteve preso nas masmorras do Rio de Janeiro, após ter sido denunciado como adepto ao ideário republicano difundido pelos revolucionários franceses de 1789 (AUTOS 
${ }^{4}$ Em Levantado do chão, romance publicado em 1980, reaparecem cenas de tortura promovidas pela polícia política, como a que levou à morte o lider comunista português Germano Vidigal.
DA DEVASSA, 2002). O "novo" do método deriva do emprego da tecnologia, representada pelo computador, incumbido de "descobrir qual delas seja [a resposta verdadeira] e a sua ligação com as outras" (p. 1087), bem como de dispensar novas explicações, pois provoca o óbito do acusado. Contudo, a verdade não será revelada, que estaria na sexagésima resposta, a que não foi dada, pois "o homem que saiu de casa depois da hora de recolher" (p. 1088) não apresentará a razão de seu ato, submetendo-se à persistência da tortura até o médico declarar que "não vale a pena" (p. 1088) prosseguir.

A cena de tortura do capítulo 4 remonta ao período inquisitorial, mas corresponde ao modo de proceder da política salazarista - a PIDE, sigla da Polícia Internacional e de Defesa do Estado - que agiu nas sombras do governo português desde os anos 1930 até os derradeiros dias da gestão de Marcelo Caetano, em 1974. Em 1975, quando O ano de 1993 foi publicado, os acontecimentos anteriores à Revolução dos Cravos estavam vivos na memória das pessoas, e a obra de Saramago não economiza palavras ao expor a brutalidade a que eram sujeitas as vítimas do sistema político vigente. ${ }^{4}$

Os capítulos seguintes intensificam a representação de uma sociedade oprimida por tropas de ocupação. Assim, o capítulo 5 anuncia uma cidade cercada, desprovida da presença humana, já que as pessoas a abandonaram: "A cidade que os homens deixaram de habitar está agora sitiada por eles / [....] / Os homens estão apenas em redor da cidade tão incapazes de entrarem nela como de se afastarem para longe definitivamente" (p. 1089).

À reificação dos seres humanos opõe-se a antropomorfização dos computadores, capacitados não apenas a identificar, mas a se manifestar, informando qual resposta é a verdadeira, dentre aquelas enunciadas pelo indivíduo torturado, como ocorre no capítulo 4 . O espaço urbano é habitado tão somente pelos lobos, invertendo-se, conforme o narrador, "a ordem natural das coisas", pois "estão os homens fora e os lobos dentro" (p. 1090). Esses não se limitam a apossarse do cenário: à noite, saem "a caçar os homens e sempre apanham algum", deixando "por onde passa[m] um regueiro de sangue" (p. 1090).

A cidade converte-se na selva, e os seres humanos, em alvos de animais ferozes. No capítulo 7, ela toma outra 
configuração, ao aparecer como território ocupado por tropas de soldados, cujo comandante conta com um feiticeiro "no seu estado-maior", a quem recorre quando lhe "apraz usar o chicote" (p. 1093). Para que possa fazê-lo, o militar vale-se dos poderes mágicos do ajudante, capaz de reduzir "a cidade ao tamanho de um corpo humano" (p. 1090). É quando exerce seu poder: "Então o comandante das tropas de ocupação faz estalar três vezes a ponta para habituar o braço e logo a seguir chicoteia a cidade até se cansar" (p. 1090).

A cidade - síntese alegórica da sociedade - que, no capítulo 6, desumanizara-se por carecer de gente que a habitasse, passa por outro tipo de antropomorfização, reduzindo-se à dimensão do corpo de um indivíduo. Objeto das chibatadas do comandante, assume as características de um escravizado, matéria da violência física de seu senhor. Subordinadas, as pessoas não reconhecem o que lhes sucede, pois, ainda que percebam os "sinais" das "chicotadas na cara" (p. 1094), ignoram a procedência das cicatrizes: "Sempre que isto acontece os habitantes ao encontrarem-se nas ruas perguntam uns aos outros que sinais são aqueles de chicotadas na cara / Quando tão seguros estão de que ninguém os chicoteou nem tal consentiriam (p. 1094). Tanto maior é a opressão, quanto mais difícil é para uma população reconhecê-la. Cabe ao narrador denunciar os fatos que caracterizam a tortura, a barbárie e a desumanização em meio a uma sociedade moderna, dotada de meios de comunicação amplamente disseminados e acessíveis.

A violação das mulheres dá sequência aos atos de crueldade perpetrados pelos vitoriosos na guerra: "Será visto que estando mortos os homens perseguidos os perseguidores hão de violá-las conforme mandam as imemoriais regras de guerra" (p. 1095). Elas, porém, apenas aparentam ceder: se, de uma parte, "silenciosamente suportam o assalto e abrem os braços", de outra, reagem, cortando, "com um estalo seco e definitivo os dentes que o ódio fizera crescer nas vulvas frenéticas", "os pênis do exército perseguidor" (p. 1096). Por meio de sua ação, as mulheres igualam-se àqueles que as atacam, ao cuspir "para fora com o mesmo desprezo com que os homens perseguidos haviam sido degolados" (p. 1096).

Consumada a ocupação, compete aos detentores do poder deixar evidente o exercício de seu mando. Assim, o capítulo 9 refere-se às ações dos recenseadores, que contam três vezes 
ao dia o número de habitantes autorizados a permanecer na cidade, enquanto o segmento seguinte dá conta das pessoas que "passaram a viver debaixo do chão" (p. 1099). No capítulo 11, o narrador relata a instalação do "olho de vigilância", o "olho que não dorme nunca", parente próximo das teletelas, que estão por toda a parte, vigiando o comportamento dos moradores locais, no romance 1984, de George Orwell. A repercussão de A revolução dos bichos, também de Orwell, em $O$ ano de 1993, aparece no trecho seguinte, quando se informa que "um dos resultados da catástrofe foi que de uma hora para a outra os animais domésticos deixaram de o ser": um macaco amestrado crucifica "a mulher do governador escolhido pelo ocupante", enquanto galinhas "arraca[m]-lhe à bicada as unhas dos pés" (p. 1103). "Velhinhas inocentes" são arranhadas por "gatos castrados de estimação" (p. 1103), e crianças agredidas por aves, deixando-as cegas.

De sua parte, o ocupante preocupa-se em reformar o "sistema prisional", construindo "edifícios de seis andares todos de vidro transparente" (p. 1104), o que faculta conferir visibilidade à prática carcerária: "Tudo quanto um preso faz o tem de fazer à vista dos outros presos dos guardas e da cidade sem espetáculos públicos" (p. 1104). Atos humanos, como "comer defecar masturbar" são expostos a todos, bem como as "sessões de interrogatórios e de tortura" (p. 1105), perpetrados à luz do dia. Com isso, "o novo sistema prisional aceita a livre observação e se oferece ao testemunho geral", conforme um processo de, na expressão de Hanna Arendt (1999), banalização do mal, possível porque, na expressão do narrador, "a mais grave ocupação de todas que é a de pensar ninguém dá atenção" (p. 1104). Neutraliza-se a violência por meio de sua exposição contínua, afiançando a permanência da opressão do grupo. O dentro e o fora da prisão coincidem, e a indignação e a rebeldia se calam.

A partir do capítulo 14, abrindo a segunda parte do poema, o relato dará conta do que aconteceu ao grupo de pessoas expurgadas da cidade, população "nomádica" e que se estrutura em "uma nova sociedade alicerçada no espírito cooperativo" (SGARBI, 2013, p. 75). Trata-se de um núcleo que retrocede aos primórdios da sociedade humana, organizado ao modo de uma "tribo ou rebanho de gente que vagueia pelos campos" (p. 1106), com seus "corpos nus" (p. 1107) aquecidos 
por fogueiras. O primitivismo dessa existência reduzida às condições mínimas de sobrevivência não impede, porém, a esperança, tema expandido no segmento subsequente.

Assim, no capítulo 15, o panorama, que inclui a natureza, caracteriza-se pela regressão, estando os homens "postos de joelhos em linha com os braços abertos recebendo no rosto a fustigação do vento e da espuma" (p. 1109), já que se encontram junto ao oceano. Vivem a "miséria extrema" (p. 1109) e a dispersão, o que assinala sua completa depauperação. Contudo, há a expectativa de mudança, quando "o mar subitamente se acalma e um lento murmúrio de um lado e do outro reconsidera os fatos" (p. 1109). É a partir desse ponto que nasce "uma coragem", necessária para esboçar uma reação, "sem o que não seria possível juntarem-se outra vez os homens e subirem a escarpa a caminho da terra ocupada" (p. 1109).

Não é ainda, porém, o tempo em que começam a se produzir mudanças: entre os capítulos 16 e 25, intensificamse as demonstrações de violência por parte do poder e de submissão por parte da população da cidade conquistada. Nessa, as pessoas desaprendem a ler (capítulo 16), enquanto os ocupantes transformam os animais, convertendo-os em eficientes máquinas de guerra, a exemplo do elefante, o mais terrível dos mecanismos criados: "Talvez quem sabe porque havia sido muitas vezes domesticado e ridicularizado nos circos quando a sua grande estatura se equilibrava numa bola absurda ou se levantava nas patas traseiras para cumprimentar o público" (p. 1113). A resistência, apresentada no décimo oitavo segmento, é aniquilada por uma força representada por "lobos mecânicos" (p. 1115). Depois, os "ocupantes", por determinação dos computadores, obrigam os habitantes da cidade a serem numerados "na testa como no braço se fizera cinquenta anos em Auschwitz e em outros lugares" (p. 1117).

O capítulo 24 devolve a atenção para o núcleo formado pela população expurgada da cidade, que, organizada de modo tribal, se refugia em cavernas, permanentemente acossada pelos ocupantes e pelas feras. Acentua-se aqui a contradição entre o avanço tecnológico dos aparelhos do poder e a privação instrumental experimentada por aquele grupo de humanos. Que, contudo, enfrenta os adversários com bravura, a ponto de derrotar os assaltantes, embora despojado de "armas a não ser os toscos paus arrancados dificilmente aos ramos mais baixos 
das árvores e as pedras roladas colhidas nos leitos das ribeiras" (p. 1128). A memória dessas lutas desiguais é registrada nas paredes das grutas, onde "alguns homens reproduziram o leão e o corvo voando e ao fundo uma cidade armada" (p. 1129). Não apenas os inimigos são representados, mas também os combatentes resistindo aos antagonistas: "Feito o que desenharam o retrato de si próprios segurando uns toscos paus e na transparência do peito limitado por dois riscos laterais marcaram o lugar que deve ocupar um coração vivo" (p. 1129). Nada muito distinto das pinturas rupestres encontráveis nos sítios arqueológicos do Vale do Côa, que podem ter inspirado o narrador de Samarago:

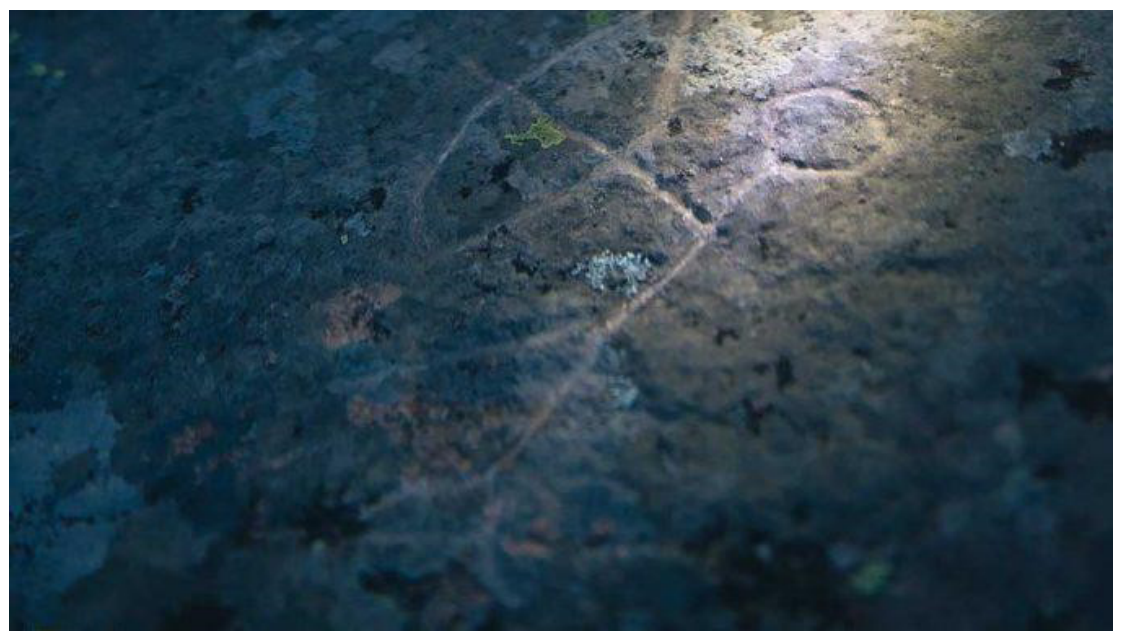

Figura 2 - Arte rupestre em Portugal

Fonte: https://nationalgeographic.sapo.pt/historia/grandes-reportagens/2115-aarte-rupestre-de-que-ainda-nao-se-fala

A alusão à arte rupestre reintroduz, na obra, a explicitação da poética que subjaz aos versos: agora não mais se trata de um produto surrealista, contendo imagens que distorcem o real para falar da falta de mobilidade e melancolia de uma população invadida. Referindo, a partir do capítulo 24, a reação - ainda que nem sempre bem-sucedida - do povo limitado a condições precárias de sobrevivência, o narrador busca uma estratégia distinta, de propensão realista, como foi a arte paleolítica, manifestação primeira do pendor criativo da humanidade.

Talvez por essa razão, o capítulo 25 comece a esboçar a reviravolta da população submissa, com o anúncio da gravidez 
de uma mulher especial. A reação toma forma a partir do segmento subsequente, o qual se completa no capítulo 27, relativo às "soltas esparsas esperanças" e ao estado de alerta dos combatentes, que aguardam os inimigos que "vem perto" (p. 1135). Nos segmentos 28 e 29 , narra-se a reconquista das cidades, o que leva à reconstrução, culminando no arco-íris que não se desvanece "nem quando o sol se p[õe]" (p. 1138). Quando o dia amanhece, a terra mostra-se livre, e o arco-íris, no último verso, anuncia um "bom sinal" (p. 1140) para os habitantes da cidade.

O final alvissareiro do penúltimo segmento sugere a pacificação, mas o capítulo 30 dá a entender que os prognósticos podem ser enganosos, sintetizados na imagem expressa nos dois parágrafos finais: "Uma vez mais o impossível ficar ou a simples memória de ter sido / Consoante se conclui de nada haver debaixo da sombra que a criança levanta como uma pele esfolada" (p. 1142)

José Saramago encerra a narrativa de modo ambíguo, procurando evitar a euforia que talvez comprometesse o tom amargo com que descreve o futuro de uma sociedade dominada por um invasor destrutivo e autoritário. Seus paradigmas provêm de regimes que predominaram na primeira metade do século XX, destacando-se as práticas próprias do governo nazista na Alemanha, textualmente citado na alusão ao campo de concentração de Auschwitz. Não é difícil, porém, reconhecer não apenas o totalitarismo stalinista, mas, em especial, a ditadura salazarista, da qual Portugal se livrara meses antes da publicação de $O$ ano de 1993.

No desenho do mundo distópico da obra, sobressai principalmente o militarismo agressivo e racista do Terceiro Reich, como o controle dos oponentes por intermédio de instrumentos policiais, processo que José Saramago presenciara em sua terra natal desde os anos 1930. À época da Segunda Guerra, o governo de Salazar não tomou partido das forças em disputa; contudo, o país enfrentava uma guerra particular nas regiões sob seu domínio na África, testemunhadas por Saramago, sobretudo ao longo da década de 1960. Assim, se o Estado lusitano não agia como um invasor que ocupava nações europeias, por outro lado, ajustava-se ao modelo de conquistador que, no continente africano, aniquilava inimigos ou conservava-os em situação de absoluta precariedade, 
${ }^{5}$ Luciana S.

Picchio sugere uma justificativa para a escolha no ano de 1993 como data para os acontecimentos relatados na obra:

“Não há aparentemente coincidências numéricas que nos indiquem o porquê da escolha do ano de 1993 para o futuro distópico de José Saramago. O próprio autor declarou ter escolhido 1993 por razões puramente fonéticas, numa série limitada de anos futuros porque lhe parecia soar melhor de (sic) 1991 ou de (sic) 1994. Mas nada nos impede ver aqui, mesmo a nível de incônscio, um jogo à Orwell com a troca dos últimos dois algarismos entre 1939 e 1993 , porque 1939 apareceria como o ano crucial da expansão planetária da guerra mundial, um ano trágico para a Península Ibérica, quando Portugal reconheceu o governo do general Franco e assinou com a Espanha o tratado de amizade e não agressão." (PICCHIO, 2000, p. 355). atribuindo a si mesmo o qualificativo de civilizado e progressista.

A composição da cidade em que residem as personagens anônimas de $O$ ano de 1993 pode ser heteróclita, constituída tanto de elementos extraídos dos regimes autoritários do século $\mathrm{XX}$, quanto de sugestões originárias das representações desses sistemas em obras distópicas das quais o livro se avizinha, como, sobretudo, de 1984, o principal modelo da narrativa. ${ }^{5}$ Mas, ainda que não nomeado, é o Portugal salazarista que subjaz no texto, sendo que se pode cogitar que a reviravolta dos últimos capítulos corresponda ao movimento conhecido como Revolução dos Cravos, que derrubou a quase cinquentenária ditadura que vigorou naquele país.

Talvez, em fevereiro de 1975, quando O ano de 1993 foi lançado, Saramago já estivesse um tanto decepcionado com o movimento que reintroduziu a democracia em sua pátria, razão por que não encerra seu poema com manifestações de júbilo; por outro lado, talvez julgasse não ser de sua competência celebrar eventos recentes. De todo modo, o escritor é cauteloso nesse livro, ao contrário do que ocorre em duas obras posteriores, o romance Manual de pintura e caligrafia, de 1978, e o drama $A$ noite, de 1980, peça de teatro em que encena, na redação de um jornal lisboeta, acontecimentos transcorridos às vésperas do 25 de abril, data da Revolução dos Cravos.

A atitude adotada assegura coerência narrativa a seu livro, modulando o andamento dos fatos. Distopias denunciam o presente ou o passado próximo, de que a atualidade é fruto. Alinhado a esse princípio, Saramago conclui seu livro em chave moderada, apontando para os riscos da esperança leviana.

\section{Direitos humanos}

Datam da segunda metade do século XVIII as obras e manifestações julgadas fundadoras das ações em nome dos direitos humanos (COMPARATO, 2003). O ponto de partida é o debate relativo à liberdade dos indivíduos, que tem em $O$ contrato social, de Jean-Jacques Rousseau, um de seus alicerces, ao proclamar, na primeira página, que "o homem nasceu livre, e em toda parte se encontra sob ferros" (ROUSSEAU, 1782, p. 3). Em direção similar, o abade Gabriel Bonnot de Mably, na Carta V, do livro Dos direitos e deveres do cidadão, de 1789, discute com 
6 "A Declaração de Independência dos Estados Unidos da América". In: http:// www.arqnet.pt/portal/ teoria/declaracao vport.html. Acesso em: 8 jun 2020.

${ }^{7}$ Declaração dos Direitos do Homem e do Cidadão. In: https:// bityli.com/wODCX. Acesso em: 8 jun 2020. o interlocutor "qual deva ser a sua conduta nas monarquias para evitar maior escravidão, e recobrar a liberdade" (MABLY, 1821, p. 89).

As reivindicações em nome da liberdade aproximam-se, de uma parte, das lutas em prol da extinção dos laços coloniais, tendo a possessão britânica na América do Norte encabeçado os processos de emancipação, quando, em 1776, seus líderes difundem a Declaração de Independência. Nos parágrafos iniciais, os Founding Fathers da república norte-americana associam liberdade e direitos, ao pronunciar: "Consideramos estas verdades como evidentes por si mesmas, que todos os homens são criados iguais, dotados pelo Criador de certos direitos inalienáveis, que entre estes estão a vida, a liberdade e a procura da felicidade." ${ }^{\prime \prime}$

A enunciação congrega, numa única afirmação, igualdade, "liberdade" e "direitos inalienáveis". Sua provável sucessora, a Declaração dos Direitos do Homem e do Cidadão, elaborada pelos revolucionários franceses de 1789, resume esses princípios no primeiro artigo do documento: "Os homens nascem e são livres e iguais em direitos."

O conceito de Direitos Humanos toma forma nas décadas finais dos setecentos, e o escopo das reivindicações se alarga, como relata Lynn Hunt (2009): na ilha de Santo Domingo, futuro Haiti, a rebelião contra o Estado francês, ao qual estava subordinada, obriga o governo revolucionário, em Paris, a aceitar as prerrogativas da população negra, mesmo quando escravizada; intelectuais feministas, como Olympe de Gouges e Mary Wollstonecraft, publicam livros e panfletos, exigindo o reconhecimento dos direitos das mulheres.

Nem todas essas pautas foram bem-sucedidas. O escravismo não se extinguiu imediatamente: passaram-se aproximadamente cem anos entre a declaração dos republicanos franceses e a emancipação da população escravizada na África e importada para o Brasil. Os direitos das mulheres, a começar pelo acesso ao voto, esperaram a passagem para o século $\mathrm{XX}$, devendo-se o retrocesso ao aparecimento e expansão de teorias científicas que postulavam a inferioridade de pretos e mulheres (Cf. HUNT, 2009, p. 187-197).

Teorias racistas, nascidas no cientificismo do século XIX, ampararam os genocídios da primeira metade dos novecentos (ISHAY, 2008; HUNT, 2009). É somente após a 
${ }^{8}$ https://bityli.com/ BlrMm. Acesso em: 8 jun 2020. vitória dos Aliados e a supressão dos regimes nazista e fascista em muitos países da Europa Ocidental, que os governos se organizam coletivamente, fundando a Organização das Nações Unidas, de onde emana a Declaração Universal dos Direitos Humanos. Considerando, na abertura desse documento, que "o reconhecimento da dignidade inerente a todos os membros da família humana e dos seus direitos iguais e inalienáveis constitui o fundamento da liberdade, da justiça e da paz no mundo", seu primeiro artigo apregoa: "Todos os seres humanos nascem livres e iguais em dignidade e em direitos" (ONU, 1948). ${ }^{8}$

A literatura, enquanto um sistema que envolve autoria, texto e recepção, não ficou indiferente ao tema. Lynn Hunt chama a atenção para o fato de que a ficção do século XVIII, representada por escritores como Jean-Jacques Rousseau, em Julie, ou La nouvelle Heloïse, ou Samuel Richardson, em Clarissa, agudizaram a sensibilidade de seu público para questões que ultrapassavam a esfera doméstica de seu círculo familiar ou social de sua classe. Romances como esses, protagonizados por por pessoas em condições de disparidades étnicas, sociais ou de gênero, não apenas alargam o âmbito da tradução de problemas coletivos ou individuais, mas mostram-nos na perspectiva do sofrimento que causam - afastando amantes, fraturando parentescos, abreviando vidas.

Resulta dessas mudanças, ocorridas no campo da mímese, uma alteração no contexto da recepção, pois, na interpretação de Lynn Hunt, desenvolve-se um sentimento de empatia ou compaixão em relação àqueles com os quais leitores e leitoras não compartilhavam proximidades de classe ou nacionalidade:

Os leitores do século XVIII, como as pessoas antes deles, sentiam empatia por aqueles que lhes eram próximos e por aqueles que eram muito obviamente seus semelhantes - as suas famílias imediatas, os seus parentes, as pessoas de sua paróquia, os seus iguais sociais costumeiros em geral. Mas as pessoas do século XVIII tiveram de aprender a sentir empatia cruzando fronteiras mais amplamente definidas. (HUNT, 2009, p. 38)

A ficção do século XVIII não se pautou pela discussão dos direitos humanos, mas preparou o terreno para que o tema aflorasse no século XIX (STEVENSON, 2017). Expressivo foi o 
${ }^{9}$ Uncle Tom's Cabin. In: https://bityli.com/ t1jLb. Acesso em: 30 mai 2020. sucesso de A cabana do pai Tomás, de Harriet Beecher Stowe, de 1851, que arrebatou o público não apenas em regiões ainda submetidas ao regime escravagista, como os Estados Unidos, terra natal do romance, ou o Brasil, mas também na Europa, onde o livro, no original ou em tradução, vendeu mais de um milhão de cópias. ${ }^{9}$

A cabana do pai Tomás sintetiza as duas instâncias em que a representação dos direitos humanos - ou de sua falta - pode se concretizar em um texto literário. Em primeiro lugar, o romance toma como ponto de partida, em seu capítulo de abertura, do reconhecimento da humanidade do escravizado. Afinal, era mandatório afiançar as qualidades e virtudes de um indivíduo de pele escura, ainda que reduzido à servidão e rebaixado à condição de mercadoria. É quando, simultaneamente, a narração denuncia os tormentos de que é vítima o cativo do título da obra, com isso mobilizando a sensibilidade do público.

É depois de consolidado esse terreno que Stowe investe na segunda instância da representação da questão relativa aos direitos: é quando, em conversa entre duas personagens, uma delas condena o escravismo, por constituir "a violação mais palpável, mais audaciosa dos direitos humanos" (STOWE, 1853, Tomo 2, p. 38).

O propósito da denúncia da violação dos direitos humanos aparece com frequência em obras publicadas no século XX, em especial após o Holocausto e a revelação dos atos de barbárie, ainda que sustentada pela tecnologia mais avançada, em campos de concentração, durante a ocupação de boa parte do território europeu pelas tropas do Terceiro Reich. Esse propósito deu margem à emergência da literatura de testemunho (SELIGMANN-SILVA, 2003), que mescla memória, depoimento e pesquisa, de que são exemplos os livros de Primo Levi.

Obras como as dele ou de Jean Améry, Jorge Semprun e Imre Kertész resultam de experiências traumáticas em campos de concentração, assim como as memórias de Graciliano Ramos (1954) e os diários de ex-dominicano Fernando de Brito (BETTO, 2009) narram seus tempos de encarceramento nas prisões do Estado Novo e da ditadura militar, respectivamente nas décadas de 1930 e 1960/1970. Mas a ficção não se absteve da questão, como evidencia o romance $O$ amor de Pedro por João, 
de Tabajara Ruas (1982). Da sua parte, O ano de 1993, de José Saramago, contribui para a consolidação dessa tendência, em uma época em que o gênero testemunhal não dispunha da visibilidade que alcançou recentemente.

O exercício da denúncia atravessa quase todas as partes da obra, referindo-se à opressão e à violência praticada contra uma população indefesa, à eliminação da dissidência, ao encerramento em campos de prisioneiros, à censura, à tortura e ao extermínio. O Estado tem componentes autoritários, e o poder vale-se de sofisticados instrumentos tecnológicos, entre os quais se destacam ferramentas como o computador (o "cérebro eletrônico" do sistema) e um olho mecânico que controla a população, localizando-a onde quer que essa se oculte. Além disso, dispõe de armamentos eficientes, como tanques de guerra e máquinas que tomam a forma de animais selvagens, capazes de encontrar as pessoas e destruí-las em suas habitações.

O Estado é dominado por militares que provêm, aparentemente, de uma potência estrangeira, constituindo, pois, uma força de ocupação. Não há, assim, qualquer identificação entre seus membros e os habitantes da terra invadida, o que debilita, e até anula, os laços de proximidade entre os dois grupos, facilitando sua erradicação. O anonimato dos integrantes do poder colabora para que se agudize a representação de uma sociedade marcada pelo autoritarismo e pelo distanciamento, impedindo qualquer hipótese de relacionamento afetivo - não por outra razão, as mulheres são estupradas pelos soldados - e humanização. Essa é introduzida pelo outro ângulo da obra, o qual dá conta das ações dos habitantes da pátria invadida. No começo do poema, eles se apresentam imobilizados e perplexos, condição que se torna mais hedionda à medida que a narrativa avança, pois parte dos moradores, a que é expelida do meio urbano, é reduzida a um modo primitivo de vida, residindo em covas e alimentandose precariamente. Esse grupo precisa reinventar a existência em sociedade e redescobrir-se pertencente à humanidade até retomar o status de cidadãos, ao reagir ao Estado despótico a que foram subordinados.

Não é ocasional o fato de que até os animais - domésticos, como gatos e galinhas, ou selvagens, como leões - sejam usados contra a população desprotegida. Esses animais, 
transformados em máquinas, são jogados contra os homens e as mulheres, evidenciando-se seu declínio na escala dos seres vivos. Mesmo assim, eles não perdem sua humanidade, traduzida inicialmente pela recuperação das relações sexuais entre parceiros femininos e masculinos.

É após esse episódio que renasce, embora pálida, a esperança. E é partir desse solo - precário, mas real - que homens e mulheres encetam o processo de insubordinação, que os leva à vitória, ainda que essa também se mostre frágil e periclitante.

Essas figuras provocam a identificação por intermédio da simpatia, pois, embora também anônimas, há um pouco delas em cada um dos leitores. A identificação é sugerida desde as primeiras páginas de $O$ ano de 1993, quando o narrador aproxima seu texto a um possível quadro de Salvador Dali, em que há uma paisagem contemplada por um par de pessoas, essas também observadas por outros dois indivíduos. Nesse jogo de espelhos, dos versos de Saramago e da pintura de Dali, traduz-se um modo de recepção marcado pelo reconhecimento de que o que ali aparece também diz respeito a quem o acolhe, isto é, cada um de nós.

A identificação é igualmente suposta, quando se verifica no poema uma revisão da história da humanidade, originalmente abrigada em cavernas, mas capaz de se expressar artisticamente, como aventa o capítulo 24 , processo que propiciará a invenção da escrita e o alargamento das alternativas de comunicação entre as pessoas. Naqueles indivíduos precarizados por consequência do emprego da ferocidade de um poder discricionário, encontramos nosso passado - mas também a hipótese de um futuro sombrio, se aquele poder não for detido.

Em decorrência da associação entre as personagens de O ano de 1993 e o que se sabe do período paleolítico, o passado a que o livro se refere não é imaginário. Também não é fruto da fantasia do escritor a relação que se pode estabelecer entre o mundo representado no texto e a trajetória da ditadura salazarista em Portugal e nas colônias africanas. Ainda que de modo alegórico, Saramago calca sua narrativa em fatos reconhecíveis que respondem pelas ações do Estado lusitano durante boa parte do século XX. 
Porque esse passado não é fabuloso ou ilusório, pode-se concluir que o futuro para o qual ele direciona nosso olhar tem condições de se materializar. A denúncia, ponto de partida de obras em que os direitos humanos são tematizados, toma o sentido de uma advertência que a própria obra de Saramago tratou de concretizar em um romance que pode ter nascido no ano de 1993, pois foi publicado em 1995. Com efeito, o Ensaio sobre a cegueira retoma e amplia os sinais lançados aos leitores do poema de 1975: também ali, seres humanos são impelidos à barbárie e a atos resultantes de seus instintos mais primários, nesse caso, não por força do exercício de um poder externo arbitrário e militarizado, mas por sua omissão diante de um evento imprevisto e indesejado.

Coerente com o prognóstico dos anos 1970, Saramago tratou de dialogar com seu público, alertando-o para a necessidade de aperfeiçoamento da sociedade, objetivo presente desde a primeira das declarações dos direitos humanos e que, por mais de dois séculos, permanece como tarefa a ser desempenhada, para que suas metas sejam, enfim, concretizadas.

\section{Direitos humanos, distopia e literatura}

Podem-se definir como sociedades democráticas aquelas que se organizam em torno do reconhecimento dos direitos humanos no modo como foram proclamados desde suas primeiras manifestações, no século XVIII. Ser livre significa não estar subordinado a laços de dependência e controle, o que não ocorre em países em que a expressão é mediada por organismos como a censura ou em locais que não dispõem de autonomia governamental por estarem submetidos a alguma potência estrangeira. Por sua vez, a igualdade supõe que, apesar das diferenças (biológicas, étnicas, culturais), os indivíduos se equivalem em valor e qualidade; em outras palavras, que nenhuma pessoa é superior à outra.

Relativamente fáceis de formular e de entender, esses princípios são difíceis de praticar: a divisão de classes, os preconceitos raciais e de gênero, o nacionalismo chauvinista, o exercício de um poder tirânico - eis um conjunto de situações reconhecíveis mesmo em países signatários da Declaração Universal dos Direitos Humanos, promulgada 
pela Organização das Nações Unidas, em 1948, ou naqueles em que os direitos humanos se tornaram uma agenda política. A tarefa de ordenar uma sociedade e um Estado, tomando-os como princípio diretor, é um desafio permanente posto às sociedades democráticas.

A literatura assumiu, entre suas incumbências, a de denunciar a desigualdade ou a falta de liberdade nos ambientes representados por meio da ficção ou da poesia. Nem sempre ela exerceu essa tarefa, pois outros propósitos também moveram a ação de artistas e intelectuais. Mas aquele ideal esteve sempre evidente, desde os diálogos de Platão até as manifestações pertencentes à chamada literatura de testemunho, tão frequentes desde as últimas décadas do século $\mathrm{XX}$ até nossos dias. Algumas dessas manifestações tomaram a forma de textos de natureza distópica, de que são exemplos os já mencionados 1984, de George Orwell, ou O conto da aia, de Margaret Atwood. Porém, nem todas as distopias tematizam questões vinculadas ao projeto dos direitos humanos: Admirável mundo novo, de Aldous Huxley, expõe os efeitos da fabricação em série e das linhas industriais de montagem, bem como da cultura de massa, mas censura, racismo, homofobia, antissemitismo ou chauvinismo estão ausentes do livro - e, se aparecem, é apenas esporadicamente.

Por outro lado, nem todas as criações artísticas em que pautas motivadas pela vigência ou não dos direitos humanos podem ser chamadas de distópicas. A literatura de testemunho, que constitui a face mais visível de representação da violência de um sistema político repressivo contra pessoas por causa de suas ideias políticas, etnia, idade, gênero, proveniência geográfica, volta-se antes a acontecimentos passados, não aos que futuramente poderão concretizar os piores temores da humanidade.

É a confluência desses dois territórios conceituais que particulariza a obra de José Saramago, evidenciando os riscos que a sociedade corre quando uma nação é tomada por um poder despótico e frenético, capacitado ao exercício de todas as violências graças ao domínio de ferramentas tecnológicas avançadas, exercido contra uma população indefesa e anônima. $O$ ano de 1993 particulariza-se também porque o escritor opta por traduzir em versos sua visão de uma sociedade dominada por uma tirania estrangeira. Produz, assim, um poema 
militante, adotando uma poética inovadora e uma posição corajosa, indispensável tanto àqueles tempos, em 1975, quanto às primeiras décadas do novo milênio, quando as ameaças anunciadas naquele período parecem se materializar.

A distopia, que parecia falar do futuro, arrisca mostrar-se atualmente um relato verídico do presente.

\section{REFERÊNCIAS}

ARENDT, Hannah. Eichmann em Jerusalém. Um relato sobre a banalidade do mal. São Paulo: Companhia das Letras, 1999.

AUTOS DA DEVASSA. Prisão dos letrados do Rio de Janeiro, 1794. 2. ed. Rio de Janeiro: EdUerj, 2002.

BALTRUSCH, Burghard. "A arte é o que fica na história". O ano de 1993 de José Saramago e as ilustrações de Graça Morais. The Bulletin of Hispanic Studies, v. 97, n. 7, p. 763-792. Jul. 2020. Disponível em https://www.academia.edu/43913106/_a_ arte_\%c3\%a9_o_que_fica_na_hist\%c3\%b3ria_o_ano_de_1993_ de_jos\%c3\%a9_saramago_e_as_ilustra\%c3\%a7\%c3\%b5es_de_ gra\%c3\%a7a_morais. Acesso em 25 set. 2020.

BETTO, Frei. Diário de Fernando. Nos cárceres da ditadura militar brasileira. Rio de Janeiro: Rocco, 2009.

COMPARATO, Fábio Konder. A afirmação histórica dos direitos humanos. São Paulo: Saraiva, 2003.

COSTA, Horácio. José Saramago: o período formativo. Lisboa: Caminho, 1997.

HUNT, Lynn. A invenção dos direitos humanos. Uma história. São Paulo: Companhia das Letras, 2009.

ISHAY, Micheline R. The History of Human Rights. From Ancient Times to the Globatization Era. 2. ed. Los Angeles: University of California Press, 2008

MABLY. Gabriel Bonnot de. Direitos, e deveres do cidadão. Lisboa: Imprensa Nacional, 1821. 
OLIVEIRA, Lucas Antunes. O animal humano: ficção especulativa e alegoria em $A$ hora dos ruminantes, de José J. Veiga, e $O$ ano de 1993, de José Saramago. Recife: Programa de Pós-graduação em Letras, 2012. (Dissertação de mestrado).

PICCHIO, Luciana Stegagno. O futuro do passado: o ano de 1993 de José Saramago. Veredas: Revista da Associação Internacional de Lusitanistas, n. 3, p. 351-362, dez. 2000.

RAMOS, Graciliano. Memórias do cárcere. Rio de Janeiro: José Olympio, 1954. 4v.

ROUSSEAU, Jean-Jacques. Du contract social. Amsterdam: Marc Michel Rey, 1762.

RUAS, Tabajara. O amor de Pedro por João. Porto Alegre: L\&PM, 1982.

SARAMAGO, José. O ano de 1993. In: . Obras completas I. São Paulo: Companhia das Letras, 2014.

SELIGMANN-SILVA, Marcio (Org.). História, memória, literatura: o testemunho na era das catástrofes. Campinas: UNICAMP, 2003.

SGARBI, Elielson Antonio. A poesia de José Saramago: análise de Os poemas possiveis, Provavelmente alegria e $O$ ano de 1993. Assis: Faculdade de Ciências e Letras de Assis, 2013. (Dissertação de mestrado).

SILVA, Fernângela Diniz. O pictórico em O ano de 1993, de José Samarago: interdiscursividade com o Surrealismo. Fortaleza: Programa de Pós-graduação em Letras, 2018. (Dissertação de mestrado).

SOUZA, R. V. O ano de 1993: um texto apocalíptico ou o prenúncio da heterodoxia religiosa em Saramago. Via Atlântica, n. 11, p. 181-185, 2007. Disponível em: http://www.revistas.usp. br/viaatlantica/article/view/50676. Acesso em: 25 nov 2020.

STEVENSON, Ana. The Great Doctrine of Human Rights: Articulation and Authentication in the Nineteenth-Century U. S. Antislavery and Women's Rights Movements. Humanity: An 
International Journal of Human Rights, Humanitarianism, and Development. v. 8, n. 3. Winter 2017. University of Pennsylvania Press. p. 413-439.

STOWE, Harriet Beecher. A cabana do pai Thomaz, ou A vida dos pretos na America. Romance Moral. Trad. Francisco Ladislau Alvares de Andrada. Paris: Rey \& Belhatte, 1853. Tomo 2.

\section{ABSTRACT \\ The Year of 1993: Dystopia and Human Rights}

The year 1993, by José Saramago, published in 1975, portrays a society invaded by a despotic foreign nation, which oppresses the native population. The date indicated in the title, as opposed to the publication of the book, points to a catastrophic future, which associates the poem with the dystopian genre. The atrocities committed violate the civil rights of the inhabitants of the occupied country. Thus, The year 1993 provides a reflection on the relationship between the dystopian genre and the practice of policies in the name of human rights in a literary text.

Keywords: José Saramago. Poetry. Dystopia. Human rights.

Regina Zilberman é Doutora em Romanística pela Universidade de Heidelberg, com estágios de pós-doutorado na London University (Inglaterra) e Brown University (Estados Unidos). Professora Associada do Instituto de Letras da Universidade Federal do Rio Grande do Sul, com atuação nos cursos de graduação e pós-graduação. Pesquisadora 1A do CNPq. 